\title{
Phytoprotection
}

\section{Nouvelles avancées / Research Breakthroughs}

Volume 85, numéro 2, août 2004

URI : https://id.erudit.org/iderudit/009831ar

DOI : https://doi.org/10.7202/009831ar

Aller au sommaire du numéro

Éditeur(s)

Société de protection des plantes du Québec (SPPQ)

ISSN

0031-9511 (imprimé)

1710-1603 (numérique)

Découvrir la revue

Citer cet article

(2004). Nouvelles avancées / Research Breakthroughs. Phytoprotection, 85(2),

67-71. https://doi.org/10.7202/009831ar d'utilisation que vous pouvez consulter en ligne.

https://apropos.erudit.org/fr/usagers/politique-dutilisation/ 


\section{Contrôle de la croissance in vitro du Fusarium verticillioides et d'autres champignons pathogènes par un nouveau pesticide à base d'iode}

\section{In vitro growth control of Fusanium verticillioides and other pathogenic fungi by a new iodine-based pesticide}

Un nouveau pesticide réussit à contrôler in vitro la croissance de plusieurs champignons pathogènes. Dans la présente étude, des chercheurs du Département d'Agriculture des États-Unis (USDA) démontrent que le pesticide AJ1629-34EC, dont l'ingrédient actif est à base d'iode, peut contrôler le champignon Fusarium verticillioides, cause d'une fusariose chez le maïs. Ces chercheurs se sont basés sur deux études indépendantes qui mettaient en évidence que ce pesticide pouvait améliorer la croissance des plantules de maïs et réduire la contamination des semences de maïs par $F$. verticillioides et des semences de basilic par F. oxysporum f.sp. basilicum. Jusqu'à présent, il n'existait aucun moyen de contrôler le $F$. verticillioides dans la culture du maïs, et ce, malgré les dangers pour la santé que représentent les toxines (fumonisines) que ce champignon produit sur les grains infestés. Une dose variant entre 1,7 à 22,6 $\mu \mathrm{g}$ $\mathrm{mL}^{-1}$ de ce nouveau pesticide permet de réduire de $50 \%$ la viabilité de 48 souches différentes de $F$. verticillioides. Ces souches se différencient par leur provenance géographique (États-Unis et autres pays), leurs plantes hôtes (mono- et dicotylédones) et leurs types sexuels. De plus, une dose moyenne de $30 \mu \mathrm{g}$ $\mathrm{mL}^{-1}$ de cet agent permet de réduire de $50 \%$ la viabilité de 22 autres espèces de champignons pathogènes. Finalement, afin de confirmer les résultats de cette étude et de mieux comprendre les effets de ce nouvel agent sur des plantes, des essais en serre et en champ s'avèreront nécessaires.

\begin{abstract}
A new pesticide has been found to control efficiently in vitro the growth of several pathogenic fungi. In the present study, researchers of the United States Department of Agriculture (USDA) discovered that the pesticide AJ1629-34EC, with its iodine-based active ingredient, can limit the growth of the fungi $F$. verticillioides., the causal agent of maize seedling blight. This research is based on two independent studies which highlighted that this pesticide could promote the growth of maize seedlings and reduce the contamination of maize seeds by $F$. verticillioides and of basil seeds by $F$. oxysporum f.sp. basilicum. Until now, there was no other way to control F. verticillioides in maize crop and this, in spite of health concerns due to the released of toxins (fumonisins) from the fungi on the infested grains. A dose ranging from 1.7 to $22.6 \mu \mathrm{g} \mathrm{mL}^{-1}$ of this new pesticide reduces by $50 \%$ the viability of 48 different strains of $F$. verticillioides. These strains are distinct in terms of geographical source (the United States and other countries), host plants (mono- and dicotyledons) and sexual types. Moreover, an average dose of $30 \mu \mathrm{g} \mathrm{mL}^{-1}$ of this agent allows to reduce by $50 \%$ the viability of 22 other pathogenic fungi. Finally, in order to confirm the results of this study and to better understand the effects of this new agent on plants, trials in greenhouse and field will be required.
\end{abstract}

Yates, I.E., J .W. Arnold, C.W. Bacon, and D.M. Hinton. 2004. In vitro assessments of diverse plant pathogenic fungi treated with a novel growth control agent. Crop Prot. 23 : 1169-1176.

Soumis par Richard Jeannotte, Université McGill, Sainte-Anne-de-Bellevue (Québec) 


\section{Un outil acoustique non destructif détectant la carie chez les arbres}

Les techniques d'imagerie non destructives gagnent de plus en plus en popularité pour visualiser l'intérieur de systèmes biologiques (végétal ou animal) tout en préservant l'intégrité physique des individus sous étude. En milieu urbain, il est souvent impératif pour des raisons sécuritaires de pouvoir évaluer la solidité des arbres. La stabilité mécanique de l'arbre s'évalue habituellement au niveau du tronc, et idéalement, on souhaite obtenir cette mesure en n'endommageant pas l'individu. Des appareils existent déjà pouvant détecter des rayons $X$, des ondes magnétiques, électriques ou radio, ou mesurant la résistance physique du bois en perçant de petits trous dans l'arbre, mais plusieurs présentent des inconvénients, dont celui d'être difficile à utiliser in situ. Récemment, un appareil de tomographie ultrasonore a été développé, celuici fonctionnant sur le principe que ces ondes, générées en frappant les capteurs à l'aide d'un petit marteau, se déplacent plus lentement dans le bois carié ou altéré que dans le bois sain. Les données recueillies sont analysées par un logiciel qui reconstitue en deux dimensions la structure interne de l'arbre. Des mesures ont été effectuées à 27 niveaux sur 10 chênes blancs et trois caryers. Les arbres furent abattus pour estimer quelle était la surface réellement affectée par la carie. Sur les 10 découpes où aucune carie n'était présente, l'appareil révélait aussi que le bois était sain. Lorsque la carie était présente, l'appareil montrait des différences variant en moyenne de $5 \%$ par rapport à la vraie valeur. Ces résultats encourageants suggèrent que ce type d'appareil pourrait devenir un outil de travail fort utile en foresterie urbaine.

\section{A non-invasive acoustic tool revealing decay in trees}

\begin{abstract}
Non-invasive imaging techniques are more and more popular to visualize the internal structure of biological systems (plant and animal) concomitant with preserving the physical integrity of the individual studied. In urban areas, it is often urgent to evaluate the solidity of trees for safety reasons. The mechanical stability of trees is usually assessed at the trunk level, and ideally, this is carried out without causing any damage to the tree. Various devices already exist that operate by detecting X-rays, magnetic, electric or radio waves, or by measuring the mechanical resistance of wood through drilling small holes within the tree, but many disadvantages are associated with these methods, not the least being the difficulty of using many of them in situ. Recently, a sonic tomography apparatus has been developed on the basis that waves, produced by tapping sensors with a small hammer, move more slowly through decayed or altered wood than through sound wood. Data are analysed using a software which reconstitutes in two dimensions the internal structure of the tree. Evaluations were made of 27 cross-sections from 10 white oak and three hickory trees. These trees were felled to assess the actual decayed areas. Ten cross-sections were found to have no decay and this was correlated by the sonic tomography analysis. When decay was present, differences between data obtained by the apparatus and actual values were on average $5 \%$. These encouraging results suggest that such a method could become an essential working tool in urban forestry.
\end{abstract}

Gilbert, E.A., and E.T. Smiley. 2004. Picus sonic tomography for the quantification of decay in white oak (Quercus alba) and hickory (Carya spp.). J. Arboric. $30: 277-281$.

Soumis par Danny Rioux, Service canadien des forêts, Sainte-Foy (Québec) 


\section{Designer marking techniques for beneficial insects}

The development of marking and tracking techniques has traditionally been intended for the study of insect pests. These techniques were secondarily applied to insect predators and parasitoids. In recent years, researchers throughout the world have begun to develop effective techniques adapted to the marking and tracking of the movement of predators and parasitoids. Understanding the dispersal characteristics of such 'beneficials' is of crucial importance for classical, augmentative, inundative and conservative biological control. Some of the methods have been used successfully with insect pests in the past but others benefit from recent progress in biotechnology and electronics. It is now possible to use inexpensive pollen markers. Microbes are being used to monitor the movements of parasitoids. Intracellular organisms such as viruses and rickettsia can be used to identify specific populations of insects while bacteria and fungi can also be used as external or internal markers to study insect movements. Protein markers are being used for studying the dispersal range of insects. A variety of molecular markers can be used to find out different patterns of behaviour. Electronic tags and a variety of radar techniques can be used to track or monitor movement of predators at different geographical scales. An increased understanding of predators and parasitoids dispersal through the micro- and macro-landscape is expected from this array of new tools designed especially for beneficial insects.

\section{Techniques de marquage conçues pour les insectes utiles}

Le développement de techniques pour marquer et suivre les insectes a traditionellement été réservé à l'étude des insectes nuisibles. Ces techniques étaient appliquées de façon secondaire à l'étude des prédateurs et des parasitoïdes. Pendant les dernières années, des chercheurs de différents pays, se sont mis à développer des techniques efficaces et adaptées au mouvement des prédateurs et des parasitoïdes. Une bonne compréhension des paramètres de dispersion de ces insectes utiles est d'une importance décisive en lutte biologique classique, augmentative, inondative et de conservation. Certaines méthodes ont déjà été utilisées avec succès avec les insectes nuisibles mais plusieurs nouvelles méthodes bénéficient des progrès récents en biotechnologie et en électronique. II est maintenant possible, et peu coûteux, d'utiliser le pollen comme marqueur. Les microbes peuvent aussi être utilisés pour suivre les mouvements des parasitoïdes. Les organismes intracellulaires tels que les virus et les rickettsies peuvent être utilisés pour identifier des populations spécifiques d'insectes pendant que les bactéries et les champignons, eux, peuvent servir de marqueurs externes pour étudier le mouvement des insectes. L'étendue de la dispersion des insectes peut être mesurée en utilisant des protéines comme marqueurs. Toutes sortes de marqueurs moléculaires peuvent servir à découvrir les patrons comportementaux. Des antennes électroniques peuvent être utilisées conjointement à différents types de radar pour étudier le mouvement des insectes prédateurs à différentes échelles géographiques. Une compréhension accrue de l'écologie de dispersion des prédateurs et des parasitoïdes dans le micro- et le macro-paysage devrait découler de ces nouveaux outils de recherche développés pour les insectes utiles.

Lavandero, B., S. Wratten, J . Hagler, and M. J ervis. 2004. The need for effective marking and tracking techniques for monitoring the movements of insect predators and parasitoids. Int. J. Pest Manag. 50(3) : 147-151.

Submitted by Gilles Boiteau, Agriculture and Agri-Food Canada, Fredericton, New Brunswick 


\section{L'importance des accouplements locaux et hors agrégat chez Trichogramma evanescens}

Chez les parasitoïdes grégaires et quasi-grégaires, la majorité des accouplements se font sur l'agrégat d'émergence. Cependant, quelques femelles vierges quittent l'agrégat chez Trichogramma evanescens, $T$. minutum, et T. pintoi (Hymenoptera : Trichogrammatidae). Un certain brassage génétique entre souspopulations semble donc possible chez ces espèces. Un système d'accouplements partiellement locaux, plutôt que des accouplements uniquement locaux, est probablement fréquent chez les trichogrammes. En plus de ce potentiel d'accouplements hors agrégat par les femelles vierges, les mâles, qui eux peuvent s'accoupler plus d'une fois, peuvent aussi contribuer à ce brassage génétique. Chez $T$. evanescens, seuls quelques mâles quittent l'agrégat sans spermatozoïdes. La majorité des mâles peuvent ainsi inséminer des femelles additionnelles suite à leur dispersion s'ils en rencontrent. Cependant, même si $T$. evanescens possède clairement un potentiel d'accouplements hors agrégat, la question de savoir si les mâles peuvent localiser les femelles, et l'importance de ces rencontres, reste encore à déterminer.

\section{Importance of on-patch and off-patch mating in Trichogramma evanescens}

In gregarious and quasi-gregarious parasitoid species, most mating occurs on the natal patch, soon after emergence. However, in Trichogramma evanescens, T. minutum and T. pintoi (Hymenoptera: Trichogrammatidae) a small proportion of females leave the patch still virgin. Some genetic exchanges between sub-populations then seem to be possible in these species. Partial local mating at different levels, instead of local mating competition, is probably common among Trichogramma. In addition to these potential off-patch matings through virgin females, males, who have enough sperm for multiple matings, can also contribute to genetic exchanges. In T. evanescens, only few males leave their natal patch spermdepleted. It suggests that most males are still able, even outside of their patch, to inseminate females encountered later. However, even if $T$. evanescens clearly has some potential for off-patch mating, the question of the ability of males to locate females, and of the importance of its occurrence, is to be determined.

Martel, V., and G. Boivin. 2004. Premating dispersion in the egg parasitoid Trichogramma (Hymenoptera: Trichogrammatidae). Environ. Entomol. $33: 855-859$.

Soumis par Véronique Martel, Agriculture et Agroalimentaire Canada, Saint-Jean-sur-Richelieu (Québec) 


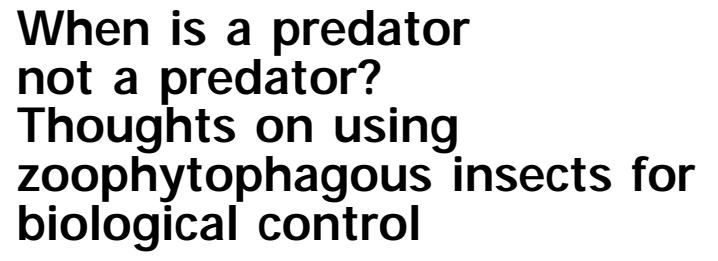

Predatory insects that feed on plants have potential to be biological control agents but also to be pests. The zoophytophagous bug, Dicyphus hesperus (Heteroptera: Miridae) is being considered for biological control of greenhouse-grown tomatoes in British Columbia, Canada. Dicyphus hesperus is a voracious predator of small soft-bodied prey such as whiteflies and lepidopteran eggs. Like other heteropterans, $D$. hesperus feeds extra-orally by injecting digestive enzymes into prey and withdrawing the prey's liquified contents through stylets. But the mirid also feeds on plant liquids, causing unsightly blemishes on tomato fruit. Why does this insect feed on plants when prey are available?

To ingest prey, to grow and to develop, D. hesperus requires water from a water source or from leaves (Gillespie and McGregor, 2000, Ecol. Entomol. 25 : 380-386). A more recent study (Sinia et al., cited below) examined the influence of prey and water availability on intake of liquids from leaves. Feeding on leaves was more frequent among mirids that preyed on lepidopteran eggs than among mirids that were not given eggs. Feeding on leaves was also more frequent among individuals without water than among those with access to water. The authors suggest that mirids feeding on plants acquire and store water for subsequent extra-oral digestion of prey, or replace water lost during predation. One interesting ecological ramification is that plants hosting $D$. hesperus may benefit from predation on herbivores but will pay costs from direct feeding by the zoophytophagous bugs. Further, the costs will increase with increasing benefit from predation.

\section{Quand un prédateur cesse-t-il d'être un prédateur? Réflexions sur l'usage d'insectes zoophytophages en lutte biologique}

Les insectes prédateurs qui se nourrissent sur les plantes peuvent devenir des agents de lutte biologique, mais ils peuvent aussi devenir des ravageurs. On examine actuellement la possibilité d'utiliser la punaise zoophytophage Dicyphus hesperus (Heteroptera: Miridae) comme agent de lutte biologique dans les serres de tomates en Colombie-Britannique, Canada. Dicyphus hesperus est un prédateur vorace qui se nourrit de petites proies à corps mou telles que les aleurodes et les œufs de lépidoptères. Comme les autres hétéroptères, $D$. hesperus se nourrit de manière extra-orale en injectant des enzymes digestives dans la proie et en aspirant, par des stylets, le contenu liqué-fié. Cependant, la punaise miride se nourrit aussi des liquides des plantes, ce qui cause des lésions peu esthétiques sur les tomates. Pourquoi cet insecte se nourrit-il des plantes lorsque des proies sont disponibles?

Pour ingérer sa proie, croître et se développer, $D$. hesperus a besoin d'eau qu'il trouve comme telle ou dans les feuilles (Gillespie et McGregor, 2000, Ecol. Entomol. $25: 380-386$ ). Une étude plus récente (Sinia et al., citée ci-après) s'est intéressée à l'influence de la proie et de la disponibilité de l'eau sur la prise de liquide des feuilles. Les mirides qui mangeaient des œufs de lépidoptères se nourrissaient plus souvent des feuilles que ceux qui n'en mangeaient pas. Les individus qui n'avaient pas accès à une source d'eau se nourrissaient aussi plus fréquemment des feuilles que ceux qui y avaient accès. Les auteurs déduisent que les mirides qui se nourrissent des plantes obtiennent et entreposent ainsi de l'eau pour de futures digestions extra-orales de proies ou remplacent l'eau perdue au cours de la prédation. Une ramification écologique intéressante qui en découle est que les plantes qui accueillent $D$. hesperus peuvent tirer avantage de la prédation sur les herbivores, mais doivent en payer le prix sous la forme d'une alimentation par la punaise zoophytophage elle-même. De plus, ce coût augmente proportionnellement à l'augmentation du bénéfice de la prédation.

Sinia, A., B. Roitberg, R.R. McGregor, and D.R. Gillespie. 2004. Prey feeding increases water stress in the omnivorous predator Dicyphus hesperus. Entomol. Exp. Appl. 110 : 243-248.

Submitted by Sheila Fitzpatrick, Agriculture and Agri-Food Canada, Agassiz, British Columbia 